\title{
PSALMS 16, 22, AND 110. HISTORICALLY INTERPRETED AS REFERRING TO JESUS
}

\author{
JOHN E. MCKINLEY* \\ Talbot School of Theology, Biola University
}

\begin{abstract}
Three Christological Psalms, 16, 22, and 110 are troublesome to modern interpreters as they are used by New Testament writers. Scholars in earlier centuries had little difficulty following the ways these psalms seemed to be counted in the New Testament as predictions of Jesus. This interpretation was continued in the Reformation but is strongly questioned by conservative and critical scholars today. The argument reviews the contextual commentary for important quotations of these psalms in the New Testament, and examines the special content of the psalms to conclude that the earlier interpreters are more trustworthy guides. The unusual New Testament usage and strange content of the psalms warrants the application of exceptional hermeneutical principles to read them properly in the biblical canon. The implications for a Christological reading of these psalms are explored for theological and practical value.
\end{abstract}

KEY WORDS: Psalm 16, Psalm 22, Psalm 110, Christology, Jesus

\section{Introduction}

I sense disagreements among scholars, and consequent confusion for evangelical readers, about the New Testament use of Old Testament passages. Critical scholars have charged that New Testament authors made things up so that what are presented as Old Testament material fulfilled in Jesus are actually illegitimate readings. Conservative scholars have replied with defenses according to ancient Jewish practices of pesher and midrash interpretation, or schemes of sensus plenior, or by specifying primary and ultimate referents, and more accounts that I do not know about. ${ }^{1}$ The task of reading

* JOHN E. McKINLEY teaches at Talbot School of Theology, Biola University.

1 Pesher is the label for the view that the New Testament authors were finding an eschatological application of the tenth century BC psalms in the first century AD events of Jesus. I acknowledge that there may be some pesher going on in the New Testament, as with the appearance of Psalm 8 in the book of Hebrews, in which case Jesus is the 
the Old Testament and New Testament together as a canon has become complicated if not disheartening for evangelical readers. This is especially the case in some of the Christological psalms. For the sake of time, I will limit my argument to Psalms 16, 22, and 110. I think the case can be made for many other psalms that Jesus is the referent and speaker, not the originnal author as a speaker referring to his own experience. Moreover, I think that at least a dozen other psalms work double-duty to express both David's experience and also that of Jesus. ${ }^{2}$ The argument could also be extended to the Messianic oracles that have been given as first-person discourses, such as Isaiah 49:1-6; 50:4-9; 61:1-4, 10-11. Like Psalm 16, 22, and 110, I think it could be argued that these Messianic oracles are given through the prophet from the historical situation of Jesus' later discourses and prayers.

I will argue that Psalms 16, 22, and 110 provide detailed accounts of Jesus' thoughts, emotions, prayers, and experiences. The New Testament specifies portions of these psalms as referring to Jesus in one way or another. It is common to interpret these psalms in the first place as expressive of the writer's experience, and, secondly, as having prophetic or typological reference to Jesus. Interpreters warn against ignoring the historical meaning for Israel and reading the New Testament usage into the Old Testament passages. $^{3}$ Generally, I agree with these principles to take each text in its historical context, and work out its canonical meaning from there.

ultimate referent of the psalm that is primarily a poetic reflection on the creation of humanity. It may be that this pesher idea may get us to the same conclusion of seeing how New Testament authors could see that Christ is indicated by these tenth century psalms, but the method is indirect and tentative so that, for having spent so much attention to the dishes, by the time we attend to the food, it has become cold. Midrash is an interpretation of applying Scripture to contemporary circumstances and issues, a re-use of a text in a new setting. Sensus plenior is a hidden meaning that is made clear through historical development of typology.

2 Derek Kidner, "Psalms 1-72", Tyndale Old Testament Commentary [TOTC] (Downers Grove, IL: InterVarsity, 1973), 18-25. Walter Kaiser has recently argued for a doubleduty interpretation in "Psalm 72: An Historical and Messianic Current Example of Antiochene Hermeneutical Theoria”, Journal of the Evangelical Theological Society (2009): 257-70. Kaiser argues for a single vision of the writer to both his own historical events and the future events of the Messiah.

3 An example of the assumption that the ancient audience should control our interpretation, along with the denial that historical distance to Jesus' life setting improves our reading is the comment on Psalm 16 in the ESV Study Bible (Wheation, IL: Crossway, 2008): "If the apostles meant that David's words were a straight prediction of the death and resurrection of Jesus, it is difficult to know what function the psalm could have 
However, for these psalms, I question if we should observe the historical reference and relevance for Israel's understanding of the meaning as our controlling interpretive principle. I think that some exceptions to the general principles are allowable, and, given the prophetic and mystically artistic features of these psalms, we should be open to some things God does as not following the general patterns. So, instead of taking these psalms as relevant in their original historical context of David's life experiences, I will argue that these psalms refer entirely to Jesus and only slightly or perhaps not at all to David (though David wrote them in the voice of first-person accounts). At least two things may be gained by allowing ourselves to read these psalms as exceptions to the general hermeneutical principle that is promoted today. ${ }^{4}$

One gain is that we can discern additional revelation of Jesus' human experience within the canon that is otherwise left off to the side or obscured by the emphasis of critical exegesis on figuring out Israel's understanding of these texts. Interpretations of these psalms as hyperbolic expressions of David's experiences and emotions seem to detract from the true referent intended by God to reveal Christ's life. I wonder if perhaps God has provided much more in the way of telling us Jesus' emotions, thoughts, prayers, and experiences in advance so that we can see his visceral, authentic humanity as depicted in a poetic way within Israel's Psalter for us.

A second gain is that we can see God's control of history and his meticulous orchestration of human events so that the facts of Jesus Christ's experiences are so definite that they can be given in advance of their occurrence in time. The words he spoke and the prayers he expressed were foretold well in advance-not as predictions, but as dictations dislocated in time. God knew and told what the Messiah would say and pray centuries in advance of the historical occurrences. This phenomenon in Scripture ought to encourage and reassure us that God is truly ruling his creation in the big and little details.

played in ancient Israel: the congregation would have scratched their heads in puzzlements every time they sang it" (956).

4 One qualification on this proposal is that I recognize that some New Testament uses of Old Testament passages are prophetic, typological, or pesher constructions. However, these methods do not cover all the New Testament usage and, I think, we have great gains to set them aside in the case of some Christological psalms. 
Argument

These Christological psalms seem exceptional among other New Testament uses of the Old Testament for two reasons. First, concerning the quoted portions from Psalm 16 and 110, Luke records Peter's denial that David is the referent for the things David wrote as first-person accounts (Acts 2:2531, 34-36; also, Paul gives the same point with the quotation in Acts 13:3537). I take this to mean that at least these quoted portions of the psalms are prophetic, in that they were given to David as the pre-recorded accounts of Jesus in a direct and possibly univocal reference. Of course, some stalwart scholars have objected to this sort of interpretation. ${ }^{5}$ Nonetheless, these psalms are exceptional, which may require an exceptional approach to interpreting them properly.

Second, these particular psalms are also unusual in their contents in a way that seems implausible to fit any experience in David's life. For example, Psalm 22 has non-metaphorical accounts that are counted by the gospel writers as exact fulfillments of Jesus' crucifixion, including at least one of his actual cries from the cross. Psalm 110 brings together the priesthood and kingship for a king of Israel in a way that was otherwise highly unusual (if not impossible) under the Mosaic Covenant, and, according to the author of Hebrews, exactly fits Jesus who is the ante-type of Melchizedek from Genesis. These psalms speak of details that just do not seem appropriate to David or anyone else, but only fit Jesus. A closer look at the exceptional and unusual evidence of the three psalms will follow in support of the claim in two steps.

The Case of Psalms 16 and 110 in Acts 2

Psalm 16 is the clearest case of a psalm that is native to Jesus' experience as a first person account written centuries earlier by David. I take this psalm as a possible paradigm for explaining how other Christological psalms should be interpreted as primarily referring to Jesus and are drawn from his life, and secondarily refer to the psalmist's experience in the tenth century BC (if at all).

5 A recent example is John Goldingay, Psalms 1-41 (Grand Rapids, MI: Baker Academic, 2006), 234. [Commenting on Psalm 16,] "While these [Christological applications in the New Testament] are all inspired and edifying reinterpretations of the psalm, we need to recognize the importance of the psalm's original meaning rather than lose its distinctive testimony. Its promise is that people who seek God's reign and God's righteousness will find that all the other things they need such as food, drink, and clothing will also be theirs".

PERICHORESIS 10.2 (2012) 
Luke's account of Peter's speech at Pentecost (Acts 2:25-32) includes a portion of Psalm 16. ${ }^{6}$ Peter identifies David as the author, but then specifies Jesus as the subject and speaker of the words quoted (Psalm 16:8-11). Peter's point is to prove that Jesus is the Messiah, having been attested by God through a miracle-working ministry (verse 22) and resurrection from the dead (verse 24). Peter cites David as a witness to the resurrection (vverse 25, 31 ), alongside Jesus' disciples who have seen the risen Christ (verse 32), and received from him the promised Holy Spirit (verse 33).

The argument for David as a witness to Jesus' Messiahship requires that David's testimony does not refer to David, but to Jesus. Peter's warrant is plain: the first person statements about confidence in Yahweh to provide bodily life after death cannot have been by David about David because David clearly died, was buried, and his bodily remains are still present (verse 29). Instead, Peter claims that even though David wrote the words, he spoke as a prophet (verse 30) concerning Jesus (verse 25) with foreknowledge of the Messiah's speedy resurrection (verse 31). Thus, Jesus is the Messiah who fulfills the promises Yahweh made to David about his enduring dynasty (verse 30; 2 Samuel 7:7-16; Psalms 132:11; 89:4). The forecast in Psalm 16 is that the Messiah would be raised from the dead quickly, without suffering bodily corruption, and this psalm confirms Jesus' identity as that very Messiah.

The case of Psalm 16 in the book of Acts has an intriguing feature. God gave David and Israel a message in the tenth century BC that could not be properly understood unless viewed in the context of Jesus Christ's life. David's knowledge of the meaning of his own words was dependent on this future orientation (verse 31). Peter's argument and explanation of the verses is a denial that the passage refers to David. If we consider Psalm 16 for ourselves, it is obvious that all eleven verses are phrased in a first person singular perspective, without a change of subject or speaker from beginning to end. We may either say one of two things.

First, we may say that we have here a mixed poem that begins with David's words about David's experience, and the psalm then rises up beyond him through mystical gift of the Holy Spirit into a prophetic statement about the Messiah's experience. Or, second, we may say that the entire psalm

For this discussion of Luke's account, I have consulted Darrell Bock, Acts (Grand Rapids, MI: Baker Academic, 2007), 123-30, and I. Howard Marshall, "Acts", Commentary on the New Testament Use of the Old Testament, [CNTUOT], ed. by G. K. Beale and D. A. Carson (Grand Rapids: Baker Academic, 2007), 513-42, 586-87.

PERICHORESIS 10.2 (2012) 
is written by David to convey the Messiah's words and experience of confidence that he would be raised from the dead. On both options, we end up with some portion of David's writing as bearing the words of another speaker and subject than himself, and the proper context is a life experience far beyond his own. Thus, as an oracle, we are provided with Jesus' prayer and hope as a true man trusting in Yahweh even in the face of his impending death.

As a matter of emphasis and priority, I think that Peter (and Luke) would have us to read the first century AD experience and speaker as Jesus, the main meaning and necessary starting place to understand the psalm rightly and receive its intended benefit to us. ${ }^{7}$ Some might object that this eclipses the relevance of the psalm for centuries of Jewish readers, but Peter reminds us in his first epistle that these prophets of old conveyed revelation about the Christ on behalf of Christian readers in later centuries, and were told something to that effect, as he writes in 1 Peter 1:12: "It was revealed to them that they were serving not themselves but you" (ESV, cf. Romans 4:2324; $15: 4$; 1 Corinthians 9:9-10; 10:11). ${ }^{8}$ That is, the Christological prophecies received in the centuries before Jesus Christ had a primary goal for people living in a later time, after the Incarnation had made all things clear.

Moreover, Paul declares that Israel, despite possessing the Old Testament prophecies, was unable to see what has given them, since "their minds were hardened. For to this day, when they read the old covenant, that same veil remains unlifted, because only through Christ is it taken away. Yes, to this day whenever Moses is read a veil lies over their hearts. But when one turns to the Lord, the veil is removed" (2 Corinthians 3:14-16, ESV). This second explanation tells the added difficulty of sin that obscured the original audience's ability to understand what they had received, which is not my point here, but this is a corollary to show that apostolic writers declared the uselessness of these oracles to the first audiences in the period before Christ. Similarly, some of the richest Messianic prophecies and oracles are given through Isaiah, who also delivers the warning from Yahweh that his first audience will hear but not understand or perceive what he offers them

7 I do not think it is necessary to exclude all reference or relevance of the psalm from touching David's experience, but that his relation to the content is as finding solidarity with it much the same as any reader today might, not primarily as his personal expressions.

8 J. Ramsey Michaels, "1 Peter", Word Biblical Commentary (Nashville, TN: Thomas Nelson, 1988), 46. Peter has given an actual case of this in Acts 2:25-36 that the prophets spoke for a later time to benefit those coming later.

PERICHORESIS 10.2 (2012) 
from God (Isa 6:9-10, a warning that seems to have in fulfillment in multiple periods, including hardened rejection of Jesus' teaching). It should not seem so strange then, that messages given during the Old Testament period were not understood or appreciated in the ways that the New Testament authors have taught us to see them. They were oracles and prophecies that could not be grasped apart from their context in the life of Jesus.

Luke is consistent in his presentation of the argument in Acts by repeating the way Paul makes the same claim from Psalm 16 in Acts 13:35-37, marking the obvious that David is not the subject of Psalm 16:10. ${ }^{9}$ (I think it is further clear that the speaker of Psalm 16:10 is the same as the speaker of verses $8-9$, and 11 , so the reference to the Holy One need not be taken as David's response to Yahweh, but the Messiah speaking to Yahweh concerning himself. The gospels tell that Jesus frequently spoke this way to refer to himself as the Son of Man. $)^{10}$

Back in Acts 2, Peter also appeals to Psalm 110, quoting verse 1 to ground his claim that Jesus is the Messiah. Peter counts David as the author, and then denies that the verse referred to David as the subject of what he wrote (Acts 2:33-36). The verse is used by Peter as proof of Jesus' exaltation and lordship alongside Yahweh (verse 33). Thus, we have a first person oracle that was written by David but not addressed to him as the subject of the psalm. Psalm 110 is different from Psalm 16 in that the content is an address to the Messiah by Yahweh, and David is involved as a witness or prophetic secretary recording the oracle and recognizing the Messiah as his own Lord. Nonetheless, I see the similarity of the primary referent of both

Kidner, "Psalms 1-72", 86, is another interpreter who sees that, based on the way Peter explains the quotation at Pentecost, the paragraph is "a prophecy of the Messiah, for whom alone such words would be perfectly and literally true $(c f ., e . g$., the always of this verse [8])".

10 Marshall, "Acts", 538, also concludes that the use of Psalm 16 in Acts 2 is the words of David's descendant that are voiced by David: "Since David could not be talking about himself in these verses (because he himself died and suffered corruption), he must have been speaking prophetically in the first person on behalf of somebody else". Marshall then responds with skepticism to the interpretation that Peter's argument is typological: "But is it appropriate to use the term 'typological' of a statement that was not true of the 'type' himself?" Bock, Acts, 138, is more cautious and calls it a typologicalprophetic interpretation: "Peter will later argue that the psalm cannot ultimately be about David and so must be about another (stressed by Bruce 1988a: 124). All this may mean that the psalm is true of Jesus in a way it is not true of David. The psalm has a unique application to Jesus, given that Jesus is the ultimate example of the pattern, escaping death through a permanent and unique exaltation to God's right hand". 
psalms to Jesus in the first century AD, not to David in the tenth century BC. If this interpretation is right, the regular hermeneutical rule is not overturned, but simply expanded to contain these exceptions that should be treated specially.

The Case of Psalms 22 \& 110

These particular psalms are unusual in their contents in a way that seems implausible to fit any experience in David's life. I think the claim holds for other psalms besides 22 and 110, but these two are the clearest. These psalms are also the two Old Testament passages that are the most quoted and alluded to in the New Testament as somehow connected with Jesus. When we consider each psalm, we find two unusual features that should alert us to treat them especially as exceptions to normal interpretive practice.

First, each psalm is counted in the New Testament as connecting with actual events and statements in the life of Jesus. Whatever meanings are intended in the psalms, at least one meaning is a direct correspondence to Jesus in the first century AD. These aspects that are recalled in the New Testament as direct depictions of true occurrences do not seem to be intelligible by readers in the tenth century $\mathrm{BC}$ in any other way than as mysterious hyperbole (which I think is unlikely, especially in view of 1 Peter 1:10-12). Neither psalm indicates that we should be thinking according to hyperbole. This feature by itself suggests that some sort of strong, direct prophecy is in play. I think these are pre-recorded messages and that they are inexplicable by either typology or pesher application, because even as hyperbole the descriptions seem too far above what could have been true for David's life. Their true context and speaker lies elsewhere. ${ }^{11}$

Second, these two psalms are definite and unique in their depictions of an execution (in Psalm 22) and an exaltation to absolute power over the entire world (in Psalm 110). Interpreters of Psalm 22 can be found to support a clear reference to Jesus, ${ }^{12}$ and there are others who argue that the psalm

11 As noted earlier, there may be a parallel between the way we read the Servant songs and Messiah testimonies in Isaiah as oracles and how we ought to read these two psalms as oracles (particularly Isaiah 52:13-53:12; 61:1-10, and etc.).

12 Kidner, "Psalms 1-72", 105, states the observation of many about the content of Psalm 22 that "No incident recorded of David can begin to account for this... the language of the psalm defies a naturalistic explanation; the best account is in the terms used by Peter concerning another psalm of David: 'Being there a prophet, ... he foresaw and spoke of ... the Christ' (Acts 2:30f.)"

PERICHORESIS 10.2 (2012) 
should not be read as referring to Jesus. ${ }^{13}$ Similarly, commentators disagree about Psalm 110, with some counting it as an oracle for the Messianic King (not for David, but written by him), ${ }^{14}$ and others denounce this view to argue that a Christian reading violates the psalm. ${ }^{15}$ I will treat each psalm in turn as to its unusual contents.

Psalm 22 was interpreted in ancient Judaism as referring metaphorically to Israel's experience or to Esther, a feature that means it is less likely that Jews saw this psalm as expressive of David's own experience. ${ }^{16}$ This is not surprising since the depictions of first person anguish include straightforward and specific descriptions of an Israelite man who narrates his experience of being executed, including the emotional and physical aspects of his anguish, and the way others treated him as already dead by gambling for his clothes (verse 18), and mocking him with reference to bold theological claims (verses 7-8). More strange are the ways that the speaker recounts two sets of paradoxical items. First, he reports that those who see him perishing mock him with specific statements, deriding him for having made theological claims (verses 7-8). This report is surprisingly given alongside the speaker's confidence that the praise of Yahweh on a global scale will result from his imminent death (verses 25-31). This conjunction of mockery for one going down to death with strong confidence in the worldwide exaltation to follow is staggering, and thoroughly alien to David's life. In a thus to the suffering of the faithful. One of the faithful who has taken it on his lips is Jesus, which reflects the depths with which it plumbs forsakenness and hope. This does not make him the primary referent of the text. It is not a prophecy. The New Testament use of the psalm "wrenches it out of its setting".

14 Kidner, "Psalms 73-150", TOTC (Downers Grove, IL: InterVarsity, 1975), 392.

15 Goldingay, "Psalms 90-150" (Grand Rapids, MI: Baker Academic, 2008), 292. [on Psalm 110] Mark 12:35-37 reflects how it would be understood messianically in Roman times, and on that basis some of its verses are applied to Jesus (e.g., Acts 2:34-35), though as a whole it does not fit him, and most of its application to him in the New Testament requires it to be understood in a way that would not correspond to its meaning in any Old Testament context", 299. "One would never guess this interpretation [New Testament exegesis] from the psalm; it can only be read into it. When YHWH spoke these words in Old Testament times, people could not have been expected to understand them as the New Testament does. ... The text's theological implications then do not lie in its application to Jesus; that is to ignore its meaning. ... We do not know and we will never know when it was written or how it was used". (300) "But canonical interpretation must mean letting different parts of Scripture have their say, not silencing some by others that we prefer". 
second paradox, the speaker tells his strong confidence in Yahweh's deliverance (verses 3-5, 9-10), and this is alongside his visceral experience of abandonment and desolation by the God who does not answer the man's cries for help (verses 1-2). The tone of protest fills the appeal that God had been faithful to Israel in the past (verses 3-5), as if to say, desperately: "Where are you now!" These are peculiar features that happen to fit Jesus' experiences closely, as the New Testament tells it with verbatim quotations from the psalm. Perhaps we should read the psalm to expand our knowledge of Jesus' experiences as reported in the Gospel accounts.

We can also see that Psalm 22 contains several aspects in its 31 verses. Portions of all the aspects of the psalm are counted in the New Testament as connected to the crucifixion and its significance. There is lament (verses 1-2, $6-8,12-18)$, including the inner sense of abandonment by God and the detailed first person descriptions of the circumstances of the execution. There are pleas for deliverance (verses 1, 19-21), confidence in Yahweh (verses 3-5, 910), and vows to praise Yahweh (verses 22-31). ${ }^{17}$ All parts of the psalm are taken by the New Testament to refer to Jesus Christ in direct ways. Only with great difficulty and stretching the possibilities of hyperbole can all parts seem anything remotely applicable to David's experience. It does not seem right to say merely that one or another part has been given for an elevated typological meaning to Jesus, since the whole of the psalm is counted as an earlier echo of him.

As with Psalm 16, Psalm 22 is written entirely in a first person voice that seems best explained by Jesus as the speaker and subject, and David as the writer who, by the Holy Spirit's revelation, conveyed these words in the tenth century BC. Thus, I know no better explanation for this psalm than to say it is alien to David's experience and properly native to Christ's experience. If this is true, then the first century $\mathrm{AD}$ is the necessary context to interpret the psalm properly and accurately. To read it apart from Jesus Christ is to catch at best a secondary value and eclipse the main thing that is intended for understanding and benefit: the cross. Consequently, to read the psalm with Jesus as the speaker from the first century AD deepens and extends our understanding of his emotional state, firm convictions, and great hope in the midst of his suffering of six hours. ${ }^{18}$ 
Psalm 110 also seems alien to David but native to Jesus. David is the writer, as confirmed by the New Testament (Mark 12:36-37), but the content tells of one who is David's Lord, and one who is also numerically distinct from Yahweh. The entire psalm, then, carries on the same subject based on the statements of Yahweh to and concerning David's Lord, whom Jesus identifies as the Messiah, calling him David's son. Moreover, there is no indication in the canon that David or anyone else styled David as a priest-king in the pattern of Melchizedek. This unique status ascribed to Jesus is bound up with the New Covenant that Jesus provides through his life and ministry. The psalm is constructed of contents that uniquely fit the Godman Messiah, both in terms of other Old Testament forecasts of his role as prophet, priest, and king, and in terms of the New Testament fulfillment of his ministry as the ascendant king and priestly sacrifice of the New Covenant. Psalm 110 simply reveals in advance how both roles come together uniquely and marvelously for the Messiah.

If we read the psalm in a non-Christological way, the ascriptions of the Lord's co-rule with Yahweh (verses 1-2, 5-7) and the Lord's eternal status as priest (verse 4) make no sense theologically for anyone other than Jesus. If we see them as referring to Christ, the psalm resonates with the canonical pictures of God as triune and Jesus Christ as the Godman. When we compare David with the psalm, we see that he cannot be in view where the subject is a human ruler of widely international scope (verses 5-6), and the function as a priest-king violates the Old Covenant limitation of the priesthood to qualified Levites. But the author of Hebrews uses Psalm 110 as the canonical revelation of Jesus Christ's unique historical role that fulfills the old and institutes the new covenant. Therefore, as with Psalm 22, this psalm is best understood and demonstrates the way that the first century AD life of Jesus Christ is the primary and proper context for interpreting the psalm accurately. Reference to David in the tenth century is misleading if Jesus is not counted first, and, I doubt the fruitfulness of finding any intended meaning in relation to David in the tenth century BC. Finally, this way of reading these psalms is the normal way, historically speaking, according to interpreters from the earliest centuries of the church.

depicted in the psalm could have been helpful for him in his human consciousness. More to consider is the way the gospel writers quote the psalm in reverse order, getting to the cry of Psalm 22:1-2 last, and how other parts of the psalm correspond to Jesus' experience in the crucifixion.

PERICHORESIS $10.2(2012)$ 
Historical Theology Witnesses to Jesus instead of David ${ }^{19}$

Our communion with ancestors in Christian faith is the share of their wisdom with us through their writings that survive the centuries. While neither they nor we are free from mistakes in our understanding of Scripture, we may follow their wisdom in this matter as with other topics unless Scripture and good sense enhanced by the Holy Spirit's leading points us to the contrary. I am relieved and refreshed to find the very things that I have been seeing in the psalms as the same conviction among the earliest interpreters in church history. I will proceed by briefly citing witness to two psalms as predominantly referring to Jesus Christ (if not exclusively). ${ }^{20}$

On Psalm 16, Athanasius, pseudo-Athanasius, Cassiodorus, Hesychius, Cyril of Alexandria, Gregory of Nyssa, John of Damascus, Theodoret of Cyrus, Origen, Jerome, and Augustine all take the psalm to be the words of Jesus Christ according to his humanity. Several are direct to say with Augustine that this speaker could only be Jesus, and no one else, not even David. ${ }^{21}$ Calvin is a witness that "this prophecy was fulfilled in the person of Christ alone". ${ }^{22}$

There is the same sort of unanimous perception of Psalm 22. Leo the Great writes: "What human ears did not yet know as about to be done, the Holy Spirit was announcing as accomplished. King David ... preceded the day of the Lord's crucifixion by more than eleven hundred years. He had suffered none of these tortures that he mentions as having been inflicted on himself. Because the Lord - who was going to take the suffering flesh from David's stock—spoke through his mouth". ${ }^{23}$ Eusebius of Caesarea writes: "The psalm refers to Christ and no one else, for its contents harmonize with none and Carmen S. Hardin, The Ancient Christian Commentary on Scripture, Old Testament VII [ACCOT] (Downers Grove: InterVarsity, 2008). timony continues in the patristic understanding of psalms that are counted in the New Testament as referring to Christ, such as Psalms 28, 41, and 45. day was in a position to say that his flesh rested in hope that his soul, not left in hell, would swiftly return to reanimate his flesh, that his flesh would not undergo corrupttion as other corpses rot away? Surely, no one can maintain that all of this was verified in David, king and prophet!"

22 John Calvin, Commentary on the Psalms, Calvin's Commentaries IV (reprint: Grand Rapids, MI: Baker, 2009), 231. Calvin is equally clear on Psalm 110 that Jesus is the only possible referent. 
other but him". ${ }^{24}$ We may also consider Martin Luther who, having explored Psalm 22 in the detail of 87 pages of exposition was convinced that the psalm referred exclusively and magnificently to Jesus. ${ }^{25}$

\section{Conclusion}

As I read psalms, I consciously identify with the experience of the author, just trying to be a good reader. For many psalms, the heading or title and background events of David's life help to inform my identification by imagining his experience and then feeling the resonance with my own. There may be instruction, reminders to hope in Yahweh, and inspiration for courage that come to me across 3,000 years from my brother's experience. I suggest that there is even more to be gained by considering and allowing Jesus Christ's life to inform my identification by imagining his experiences, and then feeling the resonance of the risen Jesus, according to his earthly life, with my own life. This engages me in relationship with him through deeper knowledge and reflection on his human experience and his ability to understand and empathize with me. The gain is to see his humanity more vividly as the reasonable pattern for my own life.

The imagining and informing of my reading of some psalms in relation to Christ happens at two levels. The first is seeing him as a reader of the same psalms that I read, and seeing that he was able to identify with David's experiences (and the experiences of other psalm authors). This is valuable for doing what Jesus did and allowing Yahweh to strengthen and inspire my life as happened for him. Any focus on Christ is going to be beneficial for the Christian, so this first level of seeing is intrinsically valuable. This is not controversial as a Christological reading.

The second level is seeing Jesus as the speaker of some of the psalms that are written out of his experience and convey his voice. I have argued that Psalms 16, 22, and 110 (among others) have primary referent to Christ variously as prayers to Yahweh, oracles to Jesus from Yahweh, first person

Proof of the Gospel 10.8.491-92, ACCOT VII, 168-69. Emphasis added.

Martin Luther, Select Works of Martin Luther, vol. IV, trans. by Henry Cole (London: Simpkin and Marshall, 1826), 354-441. For comparison, Calvin, in his comment on Psalm 22 (Commentary on the Psalms, IV, 356), is more like 21 st century interpreters, explaining the psalm as typological prophecy based partly in David's experience of distress and, "At the same time, he sets before us, in his own person, a type of Christ, who he knew by the Spirit of prophecy behaved to be abased in marvelous and unusual ways previous to his exaltation by the Father". 
accounts of Jesus Christ's hopes and fears, and models of a man's righteous trust in Yahweh. In the cases of these psalms, looking at David or other authors does not get us to the intended and primary referent, and our consequent reception of the divinely inspired revelation is refracted or eclipsed by focus on the psalm writer instead of the psalm speaker and subject (whether Christ or his Father, in the cases where Yahweh or God is speaking to the man). By comparison, the focus on the tenth century BC author of the psalm instead of the speaker and subject of the psalm is like focusing on the dishes used for a meal instead of tasting the food itself (or, at a concert, examining the musical instruments and a musician's movements while ignoring the music). Similarly, to see Christ's life as the proper context for those psalms means that we cannot receive their intended benefit otherwise or even read them accurately if we do not recognize him as the speaker and subject in the first place.

David's role (or that of another writer of a particular psalm) is more in the position of identifying with the psalm as we do, finding resonance with the speaker's experience to instruct, remind, and motivate the psalm writer, even as a songwriter or other sort of author may be moved by reflection on one's own work. The difference I propose is that in the case of these psalms, it is not one's own experience that David (or someone else, as in Psalm 45) has recorded artfully, even if the writer uses first person language of "I", "me", "my". This means that the proper starting place for interpreting these psalms is the canon of Scripture, not the tenth century BC writer, and in the canon we find strong indicators that the proper and necessary historical background for the interpretive context is in the first century AD. Thus, instead of seeing David's experiences as the primary or nearest referent for the psalm, and then seeing Christ's life as the ultimate or far referent, I suggest a reversal of putting David in the position of being the first recipient of the primary referent in Christ that has been given in advance (historically speaking, as a certain sort of prophecy like a pre-recorded account of Jesus' experiences). We, as readers in the 21 st century, come alongside David as readers feeling resonance and mystical union with Christ, though we are now looking back to what David looked ahead to in hope of the Messiah who was to come.

Moreover, reading along the lines of this reversal will allow us to see Christ's humanity in these psalms as additional material to the gospel accounts. The quotations and allusions in the gospels to these psalms are then more like hyperlinks to more revelation of Jesus Christ. This is a gain over 
seeing them as merely typological confirmations or prophetic fulfillments of specific messianic events that were foretold to Israel (but were ignored or misunderstood). I see the quotations of psalms in the gospels as portals into the direct, first person accounts of Jesus' experiences in the thought forms of Hebrew poetry. These psalms, then, transcend the tenth century BC because they are properly native to the first century AD in the rich context of the faithful life, struggle, death, and resurrection of Jesus.

\section{Bibliography}

Calvin, John. Commentary on the Psalms, Calvin's Commentaries, IV. Translated by James Anderson. Reprint, Grand Rapids, MI: Baker, 2009.

Craig A. Blaising and Carmen S. Hardin. "Psalms 1-50". Ancient Christian Commentary on Scripture, Old Testament, VII. Downers Grove, IL: InterVarsity, 2008.

G. K. Beale and D. A. Carson, eds. Commentary on the New Testament Use of the Old Testament. Grand Rapids, MI: Baker Academic, 2007.

Goldingay, John. Psalms 1-41. Grand Rapids, MI: Baker Academic, 2006.

Kaiser, Walter. "Psalm 72: A Historical and Messianic Current Example of Antiochene Hermeneutical Theoria". Journal of the Evangelical Theological Society (2009): 257-70.

Kidner, Derek. "Psalms 1-72". Tyndale Old Testament Commentary. Downers Grove, IL: InterVarsity, 1973.

. "Psalms 73-150". Tyndale Old Testament Commentary. Downers Grove, IL: InterVarsity, 1975.

Luther, Martin. Select Works of Martin Luther. Volume IV. Translated by Henry Cole. London: Simpkin and Marshall, 1826.

Michaels, J. Ramsey. "1 Peter". Word Biblical Commentary. Nashville, TN: Thomas Nelson, 1988. 